\title{
Economic performance of selected regions in Ukraine
}

\author{
Serhiy Moroz ${ }^{1}$, Ludmila Nagyová ${ }^{2}$, Elena Horská ${ }^{3}$, Zuzana Poláková ${ }^{4}$, and Dagmar \\ Cagáňová 5 \\ 1,2,3,4 Faculty of Economics and Management, Slovak University of Agriculture in Nitra, \\ Tr. A. Hlinku 2, 94976 Nitra, Slovak Republic \\ ${ }^{5}$ Faculty of Materials Science and Technology in Trnava, Slovak University of Technology in \\ Bratislava, ul. Jána Bottu 25, 91724 Trnava, Slovak Republic \\ smorozmail@gmail.com, ludmila.nagyova@uniag.sk, \\ elena.horska@uniag.sk, zuzana.polakova@uniag.sk, \\ dagmar.caganova@stuba.sk
}

\begin{abstract}
The paper considers tendencies and perspectives of the development of the chosen Ukrainian regions: Chernivtsi, Dnipropetrovsk, Kyiv, Mykolayiv, Poltava, and Ternopil regions. To carry out this study, the data were used on gross regional product (GRP) per capita, export of goods per capita, and import of goods per capita in 2002-2016. Applying the random walk with the drift model, forecasts of the monitored indicators in 2017-2019 were prepared. Based on the analyzed data, significant differences in terms of regional economic strategies were identified. It was also found out that there had been a significant gap between the best and worst regions regarding the level of economic development (i.e. GRP per capita). This situation is expected to remain the same in the prognosis period. It was concluded that, for lagging regions, it is necessary to change the strategic approaches and implement targeted measures in order to improve their economic position and competitiveness.
\end{abstract}

Keywords: regional economy, regional growth, Ukraine.

\section{Introduction}

The world experience shows that there is a need for effective and balanced regional policy, which ensures, on the one hand, a stable development of the regional economy, and, on the other hand, creates favorable living and working conditions for people. Solving this problem is important for many emerging economies, including Ukraine. This country has an appropriate potential for sustainable regional economic development. However, Ukraine is in a difficult situation due to the military conflict in the country's eastern part and annexation of Crimea and the necessity for urgent reforms of its national economy.

Several groups of factors affecting regional development could be identified. The first group is linked with innovation and knowledge. According to [1], the concept of 
Smart Specialization implies that, taking into consideration the heterogeneity of European regions, it is necessary to pay more attention on innovation than on $R \& D$ intensive industries.

[2] examine Chinese cities via a two-lens framework regarding ability of regions for innovation and sustainability. They identify that innovation activities may have positive impact on regional economic development and local sustainability index in the longterm perspective.

The second group is related to papers that explore impact of human capital on regional development. [3] explore various determinates (geographic, institutional, cultural, and human capital factors) of regional development, based on the data of 1569 subnational regions from 110 countries. They have found out that, among the abovementioned determinates, the quality of human capital has paramount importance for existence of differences of regional development.

[4] investigate how the quality of human capital affects economic development of EU's regions. Applying spatial analysis methods, the researchers confirm that the level of human capital has a substantial favorable influence on GDP per capita.

The third group of publications is connected with the influence of various businesses on the development of regions. [5] explore the effect of platform business models as an entrepreneurial ecosystem on regional economic development in South Korea. The carried out study shows that, as a result of the activities of these business models, regional development is based on multiple areas, instead of focused areas.

[6] examine the influence of export-oriented entrepreneurship on economic development of Spanish regions. As a result of their study, it is confirmed that this kind of entrepreneurship has the positive impact on regional economic growth.

From our point of view, there is a lack of studies devoted to development of regions in Ukraine. That is why the authors of the paper decided to pay attention to this topic in our paper. Its aim is to examine tendencies and to forecast future development of selected Ukrainian regions, namely: Chernivtsi, Dnipropetrovsk, Kyiv, Mykolayiv, Poltava, and Ternopil regions.

\section{Methodology}

In the present paper, the authors of the paper have analyzed the development of the ex post trend and the forecast (ex ante) of the development of selected macroeconomic indicators of GRP per capita (USD/year), export of goods per capita (USD/year) and import of goods per capita (USD/year). The original data cover 15 time periods (from 2002 to 2016). The forecast is realized for the next three years from 2017 to 2019. Our analysis was done using the Statgraphics statistical software. In the analysis, the authors of the paper processed out 5 models which have helped us in the analysis of the development over the past period, and, based on the results of the RMSE, MAE, MAPE, ME, and MPE errors, the authors of the paper chose the most suitable model (random walk with drift) for the prognosis of the monitored indicators.

The analysis has concerned six regions of Ukraine: Chernivtsi, Dnipropetrovsk, Kyiv, Mykolayiv, Poltava, and Ternopil ones. The worst, average and best regions were 
chosen intentionally in terms of the selected macroeconomic indicator - gross regional product per capita. The data were derived on the basis of publications and datasets of State Statistics Service of Ukraine. Data in Ukrainian hryvnias were converted into US dollars, using information of National Bank of Ukraine on the annual average official exchange rate of this currency to the US dollars.

\section{Results}

The choice of regions for the study was done on the basis of GRP per capita calculated for 2002. Taking into account this indicator, the authors of the paper have identified three groups of regions in terms of their economic development: the weakest regions, average regions, and strongest regions. For each group, the authors of the paper selected two examples of regions, namely:

- the weakest regions: Ternopil and Chernivtsi regions;

- the average regions: Mykolayiv and Kyiv regions (note: the authors of the paper identified these regions as nearest to the average value of GRP per capita between the Ternopil region (the weakest region) and Dnipropetrovsk region (the strongest region); see also the next note;

- the strongest regions: Poltava and Dnipropetrovsk regions (note: with respect to carried out calculations for this group, the authors of the paper excluded two regions: Kyiv (city) and Donetsk region. The authors of the paper did this for Kyiv (city) because its value of GRP per capita was by far higher than in other regions. The reason for exclusion of the Donetsk region was that it is located in the zone of the military conflict, and the region's data for 2014-2016 were available only for the enterprises, institutions and organizations that submitted reports to the state statistics bodies).

The original data cover 15 years (from 2002 to 2016). Regarding the chosen regions, the authors of the paper prepared forecasts of GRP per capita, export of goods per capita, and import of goods per capita for 2017, 2018, and 2019 in USD. On the first stage, the authors of the paper made a prognosis of GRP per capita for the three consecutive periods (Table 1 ).

GRP per capita of the Ternopil region is estimated at the level of 1195.3 USD in 2017, 1246.1 USD in 2018, and 1296.8 USD in 2019. As data were only available until 2016 at the time of writing the paper, the authors of the paper have implemented a forecast for 2017, 2018 and 2019. The years 2017-2018 can be considered as a retained sample, as currently the data for 2017 and 2018 are available and the authors of the paper can compare them with the retained sample.

Table 1. Forecast of GRP per capita, 2017-2019 (USD)

\begin{tabular}{|c|c|c|c|c|c|c|}
\hline \multirow{3}{*}{ Period } & \multirow{3}{*}{ Forecast } & Lower & Upper & \multirow{3}{*}{ Forecast } & Lower & Upper \\
\hline & & $95.0 \%$ & $95.0 \%$ & & $95.0 \%$ & $95.0 \%$ \\
\hline & & Limit & Limit & & Limit & Limit \\
\hline
\end{tabular}




\begin{tabular}{|c|c|c|c|c|c|c|}
\hline \multicolumn{4}{|c|}{ Ternopil region } & \multicolumn{3}{|c|}{ Chernivtsi region } \\
\hline 2017 & 1195.3 & 503.3 & 1887.4 & 948.6 & 235.3 & 1661.9 \\
\hline 2018 & 1246.1 & 267.4 & 2224.8 & 982.8 & -25.9 & 1991.5 \\
\hline 2019 & 1296.8 & 98.2 & 2495.5 & 1017.0 & -218.5 & 2252.4 \\
\hline \multicolumn{7}{|c|}{ The average regions } \\
\hline \multicolumn{4}{|c|}{ Mykolayiv region } & \multicolumn{3}{|c|}{ Kyiv region } \\
\hline 2017 & 2050.3 & 951.7 & 3148.9 & 3061.4 & 1425.6 & 4697.2 \\
\hline 2018 & 2140.2 & 586.6 & 3693.8 & 3218.2 & 904.8 & 5531.5 \\
\hline 2019 & 2230.1 & 327.3 & 4132.9 & 3374.9 & 541.7 & 6208.2 \\
\hline \multicolumn{7}{|c|}{ The strongest regions } \\
\hline \multicolumn{4}{|c|}{ Poltava region } & \multicolumn{3}{|c|}{ Dnipropetrovsk region } \\
\hline 2017 & 3337.9 & 1742.3 & 4933.5 & 3093.3 & 691.0 & 5495.5 \\
\hline 2018 & 3500.1 & 1243.5 & 5756.6 & 3235.8 & -161.5 & 6633.1 \\
\hline 2019 & 3662.2 & 898.5 & 6425.9 & 3378.3 & -782.5 & 7539.2 \\
\hline
\end{tabular}

Source: Own processing in Statgraphics based on the data of [7-31].

Actual real values of GRP per capita differ from the forecast point estimates; in 2017 the real value of GRP per capita in Ternopil was 1451.1 USD, in contrast to our forecast, which was 1195.3 USD. The forecast for 2018 was 1246.1 USD; the real value was 1721.8 USD. Although the point estimates are different, our forecasts are within the $95 \%$ confidence interval. It should be noted that in the forecast the authors of the paper take into account the behavior of the time series up to the point of the forecast. However, when the authors of the paper predict the development of an indicator in the future, its development is affected by various unspecified influences that the authors of the paper do not know at the time of the forecast. Therefore, the compared actual values differ from the retained sample. This fact also applies to the macroeconomic indicators set out below.

The GRP per capita of the Chernivtsi region had been expected to be 948.6 USD in 2017 (actual value was 1184.7 USD), in 2018 the forecast was 982.8 USD (actual value was 1376.5 USD) and in 2019 the forecast was 1017.0 USD.

The authors of the paper expect that the GRP per capita in the Mykolayiv region would be 2050.3 USD in 2017 (actual value was 2276.6 USD), the actual GRP per capita in 2018 was around 2585.8 USD (retained sample forecast was 2140.2 USD) and the forecast in 2019 was 2230.1 USD.

According to the forecast, the GRP per capita of the Kyiv region may have been 3061.4 USD in 2017 (actual value was 3384.9 USD), 3218.2 USD in 2018 (actual value was 4136.7 USD) and the forecast for 2019 was 3374.9 USD.

The values of GRP per capita in the Poltava region in 2017 and 2018 were calculated at 3337.9 USD (actual value was 3994.8 USD) and 3500.1 USD (real value was 4550.0 USD) respectively and the forecast for 2019 was 3662.2 USD.

Forecasts show that the GRP per capita of the Dnipropetrovsk region was expected to be 3093.3 USD in 2017 (actual value was 3652.2 USD), 3235.8 USD in 2018 (actual value was 4219.9 USD) and the forecast for 2019 was 3378.3 USD.

The second phase of our research was devoted to the forecast of the development of exports of goods per capita for the years 2017, 2018 and 2019 (Table 2). 
In accordance with the calculations, exports of goods per capita in the Ternopil region were expected to amount to 293.6 USD in 2017 (actual value was 361.2 USD), 309.4 USD in 2018 (actual value was USD 432.7) and 325.1 USD in 2019.

The authors of the paper further analyzed the Chernivtsi region. The export value of this region was estimated at 135.6 USD in 2017 (actual value was 165.7 USD), while in the following forecast years (2018 and 2019) it was estimated at 139.5 USD (actual value was USD 154.7) and 143.4 USD.

For the Mykolayiv region, its estimated values were 1517.2 USD in 2017 (actual value was USD 1659.9), 1589.7 USD in 2018 (actual value was USD 1860.5) and 1662.1 USD in 2019.

In 2017, the value of exports to the Kyiv region was estimated at 1045.6 USD per capita (actual value was 1005.6 USD), the estimated figures were 1104.3 USD (actual value was 1057.5 USD) in 2018 and 1162.9 USD in 2019.

Table 2. Forecast of export of goods per capita, 2017-2019 (USD)

\begin{tabular}{|c|c|c|c|c|c|c|}
\hline \multirow{3}{*}{ Period } & \multirow{3}{*}{ Forecast } & Lower & Upper & \multirow{3}{*}{ Forecast } & Lower & Upper \\
\hline & & $95.0 \%$ & $95.0 \%$ & & $95.0 \%$ & $95.0 \%$ \\
\hline & & Limit & Limit & & Limit & Limit \\
\hline \multicolumn{7}{|c|}{ The weakest regions } \\
\hline \multicolumn{4}{|c|}{ Ternopil region } & \multicolumn{3}{|c|}{ Chernivtsi region } \\
\hline 2017 & 293.6 & 193.0 & 394.2 & 135.6 & -34.6 & 305.8 \\
\hline 2018 & 309.4 & 167.1 & 451.6 & 139.5 & -101.2 & 380.2 \\
\hline 2019 & 325.1 & 150.9 & 499.3 & 143.4 & -151.3 & 438.1 \\
\hline \multicolumn{7}{|c|}{ The average regions } \\
\hline \multicolumn{4}{|c|}{ Mykolayiv region } & \multicolumn{3}{|c|}{ Kyiv region } \\
\hline 2017 & 1517.2 & 998.5 & 2035.9 & 1045.6 & 849.7 & 1241.6 \\
\hline 2018 & 1589.7 & 856.1 & 2323.2 & 1104.3 & 827.2 & 1381.4 \\
\hline 2019 & 1662.1 & 763.7 & 2560.5 & 1162.9 & 823.6 & 1502.3 \\
\hline \multicolumn{7}{|c|}{ The strongest regions } \\
\hline \multicolumn{4}{|c|}{ Poltava region } & \multicolumn{3}{|c|}{ Dnipropetrovsk region } \\
\hline 2017 & 1045.1 & 71.2 & 2019.0 & 1882.0 & 40.7 & 3723.3 \\
\hline 2018 & 1082.5 & -294.7 & 2459.8 & 1953.6 & -650.5 & 4557.6 \\
\hline 2019 & 1120.0 & -566.8 & 2806.8 & 2025.1 & -1164.2 & 5214.3 \\
\hline
\end{tabular}

Source: Own processing in Statgraphics based on the data of [7-31].

The export value of the Poltava region was expected to be 1045.1 USD in 2017 (real value was 1320.0 USD), the estimated level in 2018 was 1082.5 USD (actual value was 1362.0 USD) and the forecast for 2019 is 1120.0 USD.

For the Dnipropetrovsk region, the estimated export values were 1882.0 USD in 2017 (actual value was 2185.2 USD), 1953.6 USD in 2018 (actual value was 2401.7 USD) and 2025.1 USD in 2019.

The third stage of our research is related to the forecast of imports of goods per capita. The forecast is also compiled for the following three years: 2017, 2018 and 2019 (Table 3). 
In 2017, imports of goods per capita in the Ternopil region were expected to be at the level of 275.0 USD (the real value was 334.2 USD), 290.4 USD in 2018 (the actual value was 400.7 USD) and 305.9 USD in 2019.

Table 3. Forecast of import of goods per capita, 2017-2019 (USD)

\begin{tabular}{|c|c|c|c|c|c|c|}
\hline \multirow[t]{2}{*}{ Period } & Forecast & $\begin{array}{l}\text { Lower } \\
95.0 \% \\
\end{array}$ & $\begin{array}{l}\text { Upper } \\
95.0 \%\end{array}$ & \multirow[t]{2}{*}{ Forecast } & $\begin{array}{l}\text { Lower } \\
95.0 \% \\
\end{array}$ & $\begin{array}{l}\text { Upper } \\
95.0 \% \\
\end{array}$ \\
\hline & & Limit & Limit & & Limit & Limit \\
\hline \multicolumn{7}{|c|}{ The weakest regions } \\
\hline \multicolumn{4}{|c|}{ Ternopil region } & \multicolumn{3}{|c|}{ Chernivtsi region } \\
\hline 2017 & 275.0 & 125.0 & 425.0 & 109.5 & 1.1 & 217.9 \\
\hline 2018 & 290.4 & 78.3 & 502.6 & 113.2 & -40.1 & 266.5 \\
\hline 2019 & 305.9 & 46.1 & 565.7 & 117.0 & -70.8 & 304.7 \\
\hline \multicolumn{7}{|c|}{ The average regions } \\
\hline \multicolumn{4}{|c|}{ Mykolayiv region } & \multicolumn{3}{|c|}{ Kyiv region } \\
\hline 2017 & 622.4 & 326.4 & 918.4 & 1812.2 & 822.7 & 2801.7 \\
\hline 2018 & 650.2 & 231.6 & 1068.8 & 1915.9 & 516.6 & 3315.2 \\
\hline 2019 & 678.0 & 165.4 & 1190.6 & 2019.6 & 305.7 & 3733.4 \\
\hline \multicolumn{7}{|c|}{ The strongest regions } \\
\hline \multicolumn{4}{|c|}{ Poltava region } & \multicolumn{3}{|c|}{ Dnipropetrovsk region } \\
\hline 2017 & 625.9 & 200.9 & 1050.8 & 1116.4 & -146.6 & 2379.3 \\
\hline 2018 & 660.4 & 59.4 & 1261.4 & 1169.6 & -616.5 & 2955.7 \\
\hline 2019 & 694.9 & -41.1 & 1430.9 & 1222.9 & -964.6 & 3410.4 \\
\hline
\end{tabular}

Source: Own processing in Statgraphics based on the data of [7-31].

The import value of the Chernivtsi region may have been 109.5 USD in 2017 (actual value was 125.2 USD), 113.2 USD in 2018 (actual value was USD 154.7) and 117.0 USD in 2019.

The estimated import values of the Mykolayiv region were 622.4 USD in 2017 (real value was 682.7 USD), 650.2 USD in 2018 (actual value was 651.7 USD) and 678.0 USD in 2019.

Next, the authors of the paper explored the Kyiv region. Its value of imports of goods per capita was estimated at 1812.2 USD in 2017 (real value was 1958.0 USD), while in 2018 it was expected to be 1915.9 USD (actual value was 2075.0 USD) and 2019.6 USD in 2019.

For the Poltava region, the estimated values of imports per capita were 625.9 USD (actual value was 813.9 USD), 660.4 USD (actual value was 971.6 USD) and 694.9 USD in 2017, 2018 and 2019 respectively.

The import values of the Dnipropetrovsk region were expected to be 1116.4 USD in 2017 (real value was 1428.2 USD), 1169.6 USD in 2018 (real value was 1637.4 USD) and 1222.9 USD in 2019.

On the next stage, the authors of the paper summarize the data on forecasted growth of GRP, export, and import per capita in the regions in 2017-2019 in comparison with 2002 (Table 4). 
Table 4. Forecasted growth of GRP, export, and import per capita in the selected regions in 2017, 2018, and 2019 in comparison with 2002 (\%)

\begin{tabular}{|c|c|c|c|c|c|c|}
\hline Period & $\begin{array}{l}\text { GRP } \\
\text { capita }\end{array}$ & $\begin{array}{r}\text { per Export } \\
\text { capita } \\
\end{array}$ & $\begin{array}{c}\text { per Import } \\
\text { capita } \\
\end{array}$ & $\begin{array}{l}\text { per GRP } \\
\text { capita } \\
\end{array}$ & $\begin{array}{l}\text { per Export } \\
\text { capita } \\
\end{array}$ & $\begin{array}{l}\text { per Import per } \\
\text { capita }\end{array}$ \\
\hline \multicolumn{7}{|c|}{ The weakest regions } \\
\hline \multicolumn{4}{|c|}{ Ternopil region } & \multicolumn{3}{|c|}{ Chernivtsi region } \\
\hline 2017 & 175.3 & 412.4 & 536.6 & 117.8 & 76.1 & 104.7 \\
\hline 2018 & 187.0 & 440.0 & 572.2 & 125.6 & 81.2 & 111.6 \\
\hline 2019 & 198.7 & 467.4 & 608.1 & 133.4 & 86.2 & 118.7 \\
\hline \multicolumn{7}{|c|}{ The average regions } \\
\hline \multicolumn{4}{|c|}{ Mykolayiv region } & \multicolumn{3}{|c|}{ Kyiv region } \\
\hline 2017 & 192.1 & 252.3 & 203.2 & 331.4 & 529.9 & 605.4 \\
\hline 2018 & 204.9 & 269.2 & 216.7 & 353.5 & 565.2 & 645.8 \\
\hline 2019 & 217.7 & 286.0 & 230.2 & 375.6 & 600.5 & 686.1 \\
\hline \multicolumn{7}{|c|}{ The strongest regions } \\
\hline \multicolumn{4}{|c|}{ Poltava region } & \multicolumn{3}{|c|}{ Dnipropetrovsk region } \\
\hline 2017 & 268.5 & 116.2 & 479.5 & 223.7 & 132.6 & 252.0 \\
\hline 2018 & 286.4 & 123.9 & 511.5 & 238.6 & 141.4 & 268.8 \\
\hline 2019 & 304.3 & 131.7 & 543.4 & 253.5 & 150.3 & 285.5 \\
\hline
\end{tabular}

Source: Own composition based on the previous calculations in this paper.

Based on the presented data, the authors of the paper can mention some specific features of predicted economic development of the selected regions. The Ternopil region could be characterized by a significant rise of GRP, along with substantial expected growth for both export and import activities (however, import growth will be a bit higher than export growth).

Somewhat different situation is expected to take place regarding the Chernivtsi region, namely: the relatively low growth rate of GRP in combination with a slight increase of both export and import values. A significant raise will be for GRP, export, and import per capita in the Mykolayiv region. In this region, in contrast to other analyzed regions, the growth of export operations will be higher compared to an increase of import operations. The Kyiv region will have the highest growth of the above-mentioned parameters among the chosen regions. It is also expected that the export rate will go up more than the import rate in the forecasted years. With respect to the Poltava region, substantial increase will happen on GRP and the level of import, while the level of import will grow only slightly. Similar situation will be observed for the Dnipropetrovsk region. It will experience substantial growth of GRP and import value, though, the import value will go up insignificantly. 


\section{Conclusion}

The obtained research results indicate the existence of different development strategies of the above-mentioned regions, which lead to different results of their economic performance. A significant gap is identified between the strongest and weakest regions in terms of the level of economic development, and this situation is expected to remain similar over the forecast period. To bridge this gap, it is necessary to change the strategic development approaches of lagging regions and introduce targeted measures to improve their economic performance.

\section{$5 \quad$ Acknowledgements}

The paper has been written with the support of the project RIS 3 SK project scheme "Research and Development of New Creative Application Forms in the Area of Social Economics and its Influence on Integration Models Creation" (acronym KREATON).

\section{References}

1. Nordberg, K. Enabling regional growth in peripheral non-university regions - The impact of a Quadruple Helix intermediate organisation. Journal of the Knowledge Economy. 6(2), 334-356. (2015).

2. Chen, X., Li, R., Niu, X., Hilpert, U., \& Hunstock, V. Metropolitan innovation and sustainability in China - A double lens perspective on regional development. Sustainability, 10(2), 489. (2018).

3. Gennaioli, N., La Porta, R., Lopez-de-Silanes, F., \& Shleifer, A. Human capital and regional development. Quarterly Journal of Economics, 128(1), 105-164. (2013).

4. Laskowska, I. \& Dańska-Borsiak, B. The importance of human capital for the economic development of EU regions. Comparative Economic Research, 19(5), 63-79. (2016).

5. Yun, J.J., Won, D., Park, K., Yang, J., \& Zhao, X. Growth of a platform business model as an entrepreneurial ecosystem and its effects on regional development. European Planning Studies, 25(5), 805-826. (2017).

6. González-Pernía, J.L. \& Peña-Legazkue, I. Export-oriented entrepreneurship and regional economic growth. Small Business Economics, 45(3), 505-522. (2015).

7. State Statistics Committee of Ukraine Чисельність населення на 1 січня 2003 року. Retrieved from: www.ukrstat.gov.ua/operativ/ operativ2002/ds/122002.html. (2003).

8. State Statistics Committee of Ukraine Чисельність населення на 1 січня 2004 року. Retrieved from: www.ukrstat.gov.ua/operativ/ operativ 2003/ds/kn/kn_u/122003.html. (2004).

9. State Statistics Committee of Ukraine Чисельність населення на 1 січня 2005 року. Retrieved from: www.ukrstat.gov.ua/operativ/ operativ2004/ds/kn/kn_u/kn122004_u.html.

10. State Statistics Committee of Ukraine (2006). Чисельність населення на 1 січня 2006 року та середня за січень-грудень 2005 року. Retrieved from: www.ukrstat.gov.ua/operativ/operativ2005/ds/kn/kn_u/ kn1205_u.html. (2005).

11. State Statistics Committee of Ukraine Чисельність населення на 1 січня 2006 року та середня за січень-грудень 2005 року. Retrieved from: www.ukrstat.gov.ua/operativ/operativ2005/ds/kn/kn_u/ kn1205_u.html. (2006). 
12. State Statistics Committee of Ukraine Чисельність населення на 1 січня 2007 року та середня чисельність за січень-грудень 2006 року. Retrieved from: www.ukrstat.gov.ua/operativ/operativ2006/ds/kn/ kn_u/ kn 1206_u.html. (2007).

13. State Statistics Committee of Ukraine Чисельність населення на 1 січня 2008 року та середня за січень-грудень 2007 року. Retrieved from: http://www.ukrstat.gov.ua/operativ/operativ2007/ds/kn/kn_u/kn1 207_u. html. (2008).

14. State Statistics Committee of Ukraine Статистичний збірник "Регіони України" 2009. Частина II. Київ. (2009).

15. State Statistics Committee of Ukraine Чисельність населення на 1 січня 2009 року та середня чисельність за січень-грудень 2008 року. Retrieved from: http://www.ukrstat.gov.ua/operativ/operativ2008/ ds/kn/kn_u/kn1208_u.html. (2009).

16. State Statistics Committee of Ukraine Статистичний збірник "Регіони України" 2010. Частина II. Київ. (2010).

17. State Statistics Committee of Ukraine Статистичний щорічник України за 2009 рік. Київ. (2010).

18. State Statistics Committee of Ukraine Чисельність населення на 1 січня 2010 року та середня за 2009 рік. Retrieved from: http://ukrstat.gov.ua/operativ/operativ2009/ds/kn/kn_u/kn1209_u.html. (2010c).

19. State Statistics Service of Ukraine Населення України за 2010 рік. Демографічний щорічник. Київ. (2011).

20. State Statistics Service of Ukraine Населення України за 2011 рік. Демографічний щорічник. Київ. (2012).

21. State Statistics Service of Ukraine Населення України за 2012 рік. Демографічний щорічник. Київ. (2013).

22. State Statistics Service of Ukraine Зовнішня торгівля України. Статистичний збірник. Київ. (2014).

23. State Statistics Service of Ukraine Населення України за 2013 рік. Демографічний щорічник. Київ. (2014).

24. State Statistics Service of Ukraine Статистичний щорічник України за 2014 рік. Київ. (2015).

25. State Statistics Service of Ukraine Чисельність населення (за оцінкою) на 1 січня 2015 року та середня чисельність за 2014 рік. Retrieved from: http://www.ukrstat.gov.ua/operativ/operativ2014/ds/kn/kn_u/kn2014_u.html. (2015).

26. State Statistics Service of Ukraine Валовий регіональний продукт за 2014 рік. Статистичний збірник. Київ. (2016).

27. State Statistics Service of Ukraine Чисельність населення (за оцінкою) на 1 січня 2016 року та середня чисельність у 2015 році. Retrieved from: http://www.ukrstat.gov.ua/operativ/operativ2015/ds/kn/kn_u/kn1215_u.html. (2016).

28. State Statistics Service of Ukraine Валовий регіональний продукт у 2015 році. Статистичний збірник. Київ. (2017).

29. State Statistics Service of Ukraine Зовнішня торгівля України. Статистичний збірник. Київ. (2017).

30. State Statistics Service of Ukraine Чисельність населення (за оцінкою) на 1 січня 2017 року та середня чисельність у 2016 році. Retrieved from: http://www.ukrstat.gov.ua/operativ/operativ2016/ds/kn/kn_u/kn1216_u.html. (2017).

31. State Statistics Service of Ukraine Валовий регіональний продукт у 2016 році. Статистичний збірник. Київ. (2018). 